\title{
Moral Framing and the Development of Political Conflicts: An Analysis of New York Times' Stories in the Build up to the 2003 Iraqi War
}

\author{
By Vitalis Torwel
}

The declaration by former head of the US Iraq Survey Group to the US Senate Armed Services Committee that there was no evidence of Weapons of Mass Destruction (WMD) in Iraq renewed calls for the scrutiny of the Bush administration's case for war. Claims by the administration that Iraq was developing WMD and links with Al Qaeda were criticized as either not true or exaggerated to influence American public opinion and win popular support for the 2003 Iraqi war. Using New York Times as a case, this study examined the role the news media played in forming public opinion in support for or against the war. The study, conducted through content analysis, found that US official pro-war moral frames dominating the stories of the conflict in the buildup to the war. And by giving prominence and dominance to official US sources and their moral frames in support of the war, while excluding pro-diplomatic frames, New York Times stories exerted a "strong emotive appeal" on the US public and provided a moral justification for the 2003 Iraqi war.

Keywords: content analysis, Iraqi war, moral framing, New York Times

\section{Introduction}

The declaration on January 28, 2004 by David Kay, former head of the US Iraq Survey Group to the US Senate Armed Services Committee that there was no evidence of Weapons of Mass Destruction (WMD) in Iraq (The New York Times Jan. 29, 2004, p. A26) renewed calls for the scrutiny of the Bush administration's case for war. Many political analysts argued that claims made by the administration that Iraq was developing WMD and had links with $\mathrm{Al}$ Qaeda were either not true or exaggerated to influence American public opinion and win popular support for the 2003 Iraqi war. As demonstrated by opinion polls, before the war more than half of the United States' population believed Iraq was producing WMD and, therefore, supported military action to disarm Iraq (Gallup.com, March $7^{\text {th }}, 2003$ ). Consequently, news media analysts have questioned the news media's role in the formation of public opinion and the framing of support for the 2003 Iraq war (Rendall \& Broughel, 2003). Built on this assumption of media influence on public opinion, this study examines the relationship between the official US government rhetoric supporting the 2003 Iraq war and the news framing of the conflict prior to the war. Taking as a case study, the New York Times (NYT) news stories of the conflict in the period preceding the war are analyzed to examine if they reinforced or challenged the US official government war rhetoric.

* Senior Lecturer, Benue State University, Nigeria. 
The objective of the study is to assess the role of the news media in the development of international conflicts. Many studies on the news media and international conflicts have generally focused on the nature of war coverage (Atkinson, 1999; Halliday, 1999; Leopold, 1999; McNulty, 1999; Sofos, 1999) rather than on pre-war coverage, which is a crucial period for public opinion formation for or against war. Machiavelli (1521) in The Art of War describes this period as the period when people are "animated for war" (as cited in Smith, 2002 , p. 2). Seaton (1999) describes this period as a period when moral justification is sought for or against war. Thus, in the prewar period moral rhetoric is the endgame as the idea is not just to subdue the enemy, but to do this in a seemingly morally justified manner (Smith, 2002). It is hoped that the findings of this study will offer a framework for explaining the news media's role in the development of international conflicts.

\section{Moral Framing and Political Conflicts}

Moral framing is the public use of language that makes an explicit distinction between good and evil, and justifies a moral cause for action. It is a language, which in conflict situations defines one party as the aggressor and the other party as "virtuous and victimized" (Smith, 2002, p.2). In the case of the 2003 Iraqi conflict, the official moral rhetoric was that Saddam Hussein's Iraq violated UN resolutions and was producing WMD, and that Saddam Hussein was involved with Al Qaeda network or supporting terrorism, and therefore posed an imminent threat to peace, the United States, the Iraqi people, the Middle East region, and the rest of the world. President Bush's Iraqi speeches of 2001-2003 continuously re-echoed these moral frames describing Iraq as part of an "axis of evil" (www.whitehouse.gov).

Theoretically, moral frames influence news media audiences' "cognition and judgments" (Domke, Shah, \& Wackman, 2000, p. 642). When the moral frames of one party in a conflict are reinforced through the news media, it provides moral force to the presumed "right" party and a justification for the eruption of hostilities against the presumed "wrong" party in the conflict. The justification for war, according to this theoretical construct, begins with the moral framing of the enemy. According to Seaton (1999), by depicting the enemy as "a mad and ravaging tyrant" the enemy is demonized and this serves as a justification for eventual attack on the enemy (p. 46). Peters (2003) describes this as the "rhetoric of righteous victimage" where one side is identified as the victim and the other the aggressor and "there is a curious tie between the unexceptionable moral command to feel with pain (for the victims) and the contingent program of fighting (the aggressor)" (p. 2). The binary positioning of two parties in a conflict as "right" or "wrong", "good" or "evil" is the framework through which moral framing is achieved in news media texts.

In conflict situations, moral frames of actors enter the news media through the official rhetoric in speeches, press releases, and interviews. According to 
Andsager (2000), in mediating the official rhetoric, the news media do not merely convey the information, but rather "news coverage plays a substantial role in shaping public opinion via the frames that shape the way journalists report the news" (p. 578). Many framing effect studies have demonstrated the potential effects of media frames on audience perception of issues (Dickerson, 2001; Fuglsang, 2001; Pan \& Kosicki, 2001; Paterson, 2001; Shah, Domke, \& Wackman, 2001; Zoch, 2001). And this suggests that in conflict situations where it is common to find opposing parties advancing their frames about what is right and what is wrong (Domke, Shah, \& Wackman, 2000, p. 641), when the news media do not provide avenues for dialogue or critical evaluation of contending frames, but reinforce the moral frames of a party in the conflict, it legitimizes such frames.

\section{Conceptual Framework}

The news framing perspective informs this research. News framing is the selective representation of reality. Entman (1993) defines framing as

to select some aspects of a perceived reality and make them more salient in a communicating text, in such a way as to promote a particular problem definition, causal interpretation, moral evaluation, and/or treatment recommendation (p. 52).

The above definition of framing describes two related procedures: selection and salience, and it suggests four functions of framing: defining problems, diagnosing causes, making moral judgments, and suggesting remedies (Maher, 2001, p. 87-88). This paper discusses primarily the moral evaluation function of framing, which in this study is termed moral framing.

Media research has shown that news frames significantly influence audience perception of public issues (Ghanem, 1997; Iyengar, 1991; Rhee, 1997). Moral frames, for instance, appeal to value judgment (Domke, Shah, \& Wackman, 1998) by imploring "techniques of delegitimation ... and demonization" (Detenber, McLeod, \& Malinkina, 1999, p. 5). The use of moral frames is typically common in situations of political conflict where the issue of right is at stake. According to Domke, Shah, and Wackman (1998) moral frames are employed by political actors as "moral referendums" that appeal to values or morality to legitimize their position while at the same time delegitimizing the position of their opponent. Andsager's (2000) study of prolife and pro-choice interest group frames shows the dynamics of moral framing of issues by interest groups in which the moral rhetoric is strong to win public sympathy and public support.

The power of frames is in their exclusivity as use of particular frames in news serves to silence other frames. Downs (2002) explains that a "frame of reference determines which information seems relevant and which does not (as) different frames make different information relevant and tend to silence 
information irrelevant to a given frame" (p. 51). Through careful organization of thoughts, words, phrases, sentences and paragraphs, media frames represent events and people in particular ways and this can influence opinion of how the events or people are viewed by others.

Framing is widely used in the news media, however, because it serves multiple functions for different actors (Norris, Kern, \& Just, 2003, p. 11). Gitlin (1980) explains that for journalists it serves the discursive function by enabling "journalists to process large amounts of information quickly and routinely and to package it for efficient relay to their audiences" (p. 7). And in this sense news framing is viewed not as a distortion of facts, but as a routine news-making practice that helps journalists to carry out their daily functions with some ease by relying on "familiar news frames and interpretation of events offered by credible sources to convey dominant meanings and make sense of the facts" (Norris, Kern, \& Just, 2003, p. 4).

Some scholars argue that frames perform ideological functions in news. These scholars assert that what is represented in the news media are the frames of society's dominant groups (Dickerson, 2001; Durham, 2001; Gitlin, 1980; Shoemaker, \& Reese, 1996). These scholars further argue that in cases of conflict, out-groups, opposed to the dominant groups in society, are likely to be depicted in a negative way (Gitlin, 1980). Hertog's (2000) study of the US elite press coverage of the 1986 US-Libya conflict is a good example of negative portrayal of out-groups in the context of international conflict coverage. Hertog's (2000) study introduces the concept of "public patriotism" as an ideological tool and "a source of influence" on the negative portrayal of outgroups in US media coverage of international conflicts in which the US is involved. A key finding of the study is that there is a "patriotic fervor ignited by conflict" involving the US; and therefore "journalists' feelings of patriotism lead to supportive coverage" and negative portrayal of the opponent (p. 614). Hertog's findings are consistent with Graber's (1980) earlier theoretical postulation that when a conflict involves the US "the media abandon their adversary role ... (and) become teammates of officialdom" (as cited in Hertog, 2000, p. 614).

The findings of Hertog's (2000) study fit into this study's framework of examining how US government official sources were used in the framing of stories of the 2003 US-Iraqi conflict in the NYT. The importance of sources in what becomes news is well discussed by scholars. Ericsson, Baranek, and Chan (1991) define news stories as texts of the social world re-created by journalists and their sources. These scholars view sources as the key knowledge outlets journalists use to construct news (Ericsson, Baranek, \& Chan, 1991). In a study that compared quality and popular news coverage of crime and justice in newspaper, television and radio in Toronto region of Canada, Ericsson, Baranek, and Chan (1999) identified five major types of sources that contribute knowledge to news and found that the news media tend to favor governmental and institutional sources over other news sources (p. 187). Individual and noninstitutional sources, they found, are used only to provide "public reaction" to events already framed by institutional sources in the news. This suggests that 
the definition of events by official sources could easily become the defining frame in the news media when sources in official position are privileged.

\section{Research Questions}

Informed by the above theoretical perspectives on framing as selective representation of reality, the following questions will guide this study:

1. How was the case for or against the 2003 Iraqi war morally framed in the New York Times in the build up to the war?

2. How did the New York Times use news sources to reinforce or challenge the US government official rhetoric for the war?

\section{Methods}

To respond to the two research questions, The New York Times stories on the Iraqi conflict in the five months period before the start of the 2003 Iraqi war were analyzed. This five-month period corresponds with the time when the US House voted on October 10, 2002 authorizing the US President George W. Bush to employ the use of force to disarm Iraq if necessary, and the President's national address on March 19, 2003 formally declaring war on Iraq (www.whitehouse.gov).

The choice of New York Times for this study is informed by its elite status and wide readership considering its location in one of the country's biggest cities and as one of the best papers in the US (Hawk, 1992; Wakiaga, 1998; Hertog, 2000). Its numerous Pulitzer prizes for foreign news coverage attest to its role in international correspondence and significance. Thus, even though almost every paper in the US covered the US-Iraq conflict in the period before the war, because it was impractical to study each one of them it was most appropriate to settle for The New York Times, described "the best of American journalism" (Hertog, 2000, p. 615).

The study is conducted using deductive content analysis. Content analysis is "a research technique for systematic and quantitative description of the manifest content of communication" (Berelson, 1952, p. 18). By definition content analysis is quantitative and its purpose is "to identify and count the occurrence of specified characteristics or dimensions of texts, and through this, say something about the messages, images, representations of social texts and their wider social significance" (Hansen, Cottle, Negrine, Newbold, 1998, p. 95).

The suitability of content analysis for this study is informed by its primary concern with observing manifest rather than latent content of the sampled stories. It is not a co-incidence that content analysis as a formal method of social science inquiry developed in the period between the two World Wars. The initial concerns then, which are also the concerns of this study, are to 
evaluate "the contribution of the mass media to international conflict" (Hansen, Cottle, Negrine, Newbold, 1998, p. 92). Furthermore, content analysis is most suitable in studying media frames as it enables the observation of the two framing processes of selection and salience. Content analysis makes it easy to monitor the processes of selection and salience through observation of recurring themes, frequencies of frames and the number and type of sources used in each story.

The organization of the rest of the methods section follows the format used by Hertog (2000) in his study of elite press coverage of the 1986 US-Libya conflict. This is largely due to the effectiveness of the framework and the relatedness of Hertog's (2000) study to the present research.

\section{Text Sample}

The data for the study were electronically identified through Lexis-Nexis search themes: "Iraq" and "war" or "military action" or "diplomatic means". The search terms returned 1,110 stories within the time frame of the study; and the identified stories were randomly sampled for the study. Based on a sample size of 200 stories out of a total of 1,110 identified, every fifth story in the entire five-month period was selected for the study. The 200 stories were analyzed against frame variables as well as source variables. Both the frame and source variables were defined by direct reference or attribution.

\section{The Coding Instrument}

To enable the coding of the data, the researcher conducted an extensive and close study of the US war rhetoric in speeches and press statements of the US president, the national security adviser, the Secretary of State, the Defense Secretary, and other US official sources; as well as statements and releases of officials of countries and bodies that favored diplomatic means as opposed to war such as Germany, France, Russia, Iraq, etc, the UN and anti-war groups. The coding of the data followed two steps - the moral frames were coded first, and then the sources. The moral frames were identified from the stories as deontological (negative) or consequential (positive) depending on whether they represented negatively or positively the case for war. Both frames were coded pro-war. And frames that favored diplomatic settlement of the conflict to war were identified as alternative frames and coded pro-diplomatic.

The coding of the moral and alternative frames utilized the deductive analytic approach, which "involves predefining frames as content analytic variables to verify the extent to which these frames occur in the news" (Semetko \& Valkenburg, 2000, p. 94). And to codify the rationale for the war into negative or positive frames, the study employed Lichtenberg's (2001) classification of the motivation for retaliation as deontological and consequential. Lichtenberg's discussion of deontological and consequential rationale for retaliation is consistent with the idea of negative and positive moral frames in this study. Although Lichtenberg's study examines the ethics 
of retaliation and deals with the issue of punishment, her idea of deontological and consequential motives for moral action are useful in understanding how the motivational moral frames in this study have been coded as negative or positive.

Negative frames. The concept of deontological rationale for moral action is described as "backward-looking" and negative as "it justifies retaliation purely in terms of the justice of meting out punishment to one who has deliberately caused harm to others" (Lichtenberg, 2001, p. 4). The frame of reference or motivating factor is "not any supposed good consequences, but simply that the guilty party has done wrong and deserves to pay" (p. 4). Negative moral frames are defined in this study in the deontological sense of negative motivation. And they refer to frames that delegitimize and demonize the actions or attitudes of the opponent in a conflict.

The negative frames in this study include frames that appealed to the negative attitude of the Iraqi officials or administration such as direct reference or attribution to Saddam Hussein as evil, direct reference or attribution to Iraq as a theatre for the production of weapons of mass destruction; direct reference or attribution to the Iraqi regime as a threat to its Middle East neighbors, a threat to the US and a threat to the world; or linking Saddam with the September $11^{\text {th }}$ attacks, the Al Qaeda terrorist network or terrorism in general.

Positive frames. The consequential rationale for moral action is described as "forward-looking" and positive as the motivation for retaliation or moral action is to bring "about some supposed good consequences" (Lichtenberg, 2001, p. 4). Positive moral frames are defined in this study in the consequential sense, as their motivation is the positive outcome of a moral action. Positive moral frames, therefore, appeal to positive moral value as a basis for action, such as the promotion of the cause of democracy in Iraq, the liberation of the Iraqis, and the promotion of freedom and peace in the Middle East. These are motivations for the war that made direct reference to a positive motif.

Alternative frames. Alternative frames are coded as frames that favored diplomatic settlement of the conflict as opposed to war. These include frames that rationalized and advanced diplomatic alternatives to war such as allowing more time to the UN arms inspectors, war should be a last resort, war will cause more problems in the Middle East region, war will bring more suffering to the Iraqi civilians, etc.

Sources. Sources were coded in three major categories as US official sources, alternative sources and Iraqi sources. This involved identifying the sources in each sampled story. US official sources were coded as sources from the Whitehouse, the secretariat of State, US Intelligence agencies, the defense department, the national security adviser's office, the Homeland security, and all organs of the US government. Alternative sources were coded as all other sources that were not associated with the United States, such as France, Germany, Iraq, Russia, the UN, etc. Iraqi sources were coded separately given Iraq's stake in the conflict.

Both frame and source variables were defined by direct reference or attribution. A two-person inter-coder reliability test on 25 sampled stories 
using Scott's pi returned a result of $76 \%$ agreement on the frame variables and $84 \%$ agreement on the source variables.

\section{Analytic Procedure}

The stories of the New York Times in the five-month period before the 2003 Iraqi war were analyzed using two framing techniques of prominence and dominance (Bowie, 1999). Prominence is the level of importance assigned to a frame or source. Prominence is measured by the placement and positioning of a frame or source in a story in comparison with other frames or sources. Dominance is providing more space to a frame or source in story above other frames or sources. This is measured by the frequency of frames and sources within a story or within a number of stories.

To answer the first research question as to how the case for or against the 2003 Iraqi war was framed in the New York Times in the buildup to the war, moral and alternative frames were analyzed for dominance and prominence. Table 1 presents a breakdown of frame predominance by the number of stories. An analysis of the breakdown shows that pro-war moral frames were predominant with the weapons of mass destruction (WMD) frame present in 99 stories within a range of 1-11 appearances per story and a sum total of 225 times. This is followed by the Saddam is evil frame appearing in 61 stories within a range of 1-9 appearances per story and a sum total of 95 times. Conversely, the highest ranked anti-war alternative frame in terms of dominance is the preference for diplomatic means frame which is present in 34 stories within a range of 1-3 appearances per story and a sum total of 49 times.

When pro-war moral frames are compared with alternative frames in terms of dominance there is a significant difference between the two types of frames with pro-war moral frames dominating the stories. The predominance of the pro-war moral frames is reinforced by the prominence of the frames as shown in Table 2a, which summarizes the placement of moral frames in the stories. A breakdown shows that $55.6 \%$ of the stories with 3 or more pro-war moral frames appeared in the front page, with $24.8 \%$ of stories with 3 or more frames appearing on the front section and $17.9 \%$ in the back section. The difference is significant, $X^{2}(4, \mathrm{~N}=198)=25.83, \mathrm{p}<0.001$. 
Table 1. Frequencies of Frames

\begin{tabular}{|l|c|c|c|}
\hline Frame & N of stories & $\begin{array}{c}\text { Range within } \\
\text { stories }\end{array}$ & $\begin{array}{c}\text { Total } \\
\text { occurrences }\end{array}$ \\
\hline Weapons of mass destruction & 99 & $1-11$ & 225 \\
\hline Saddam evil & 61 & $1-9$ & 95 \\
\hline Iraq violated UN resolution & 34 & $1-5$ & 56 \\
\hline Diplomatic means preferred & 34 & $1-3$ & 49 \\
\hline More time to UN inspectors & 30 & $1-3$ & 42 \\
\hline War will cause more problems & 17 & $1-5$ & 30 \\
\hline Iraq/Saddam had links with al qaeda & 12 & $1-6$ & 26 \\
\hline Saddam/Iraq had links with terrorism & 18 & $1-5$ & 25 \\
\hline To promote democracy/Iraqi freedom & 18 & $1-4$ & 22 \\
\hline Threat to the Iraqis & 16 & $1-3$ & 21 \\
\hline Threat to the United States & 13 & $1-4$ & 20 \\
\hline Threat to the Middle East region & 16 & $1-2$ & 18 \\
\hline War will cause suffering & 9 & $1-6$ & 18 \\
\hline War is not the answer & 7 & $1-7$ & 16 \\
\hline War should be a last resort & 7 & $1-1$ & 7 \\
\hline Saddam/Iraq had links with Sept. 11 & 4 & $1-4$ & 7 \\
\hline Preemptive war dangerous & 4 & $1-2$ & 5 \\
\hline
\end{tabular}

Source: Author's estimations.

Table $2 \mathrm{~b}$ shows the placement of anti-war alternative frames in the stories with $11.1 \%$ of stories with 3 or more alternative frames appearing on the front page, $16.8 \%$ appearing in the front section and $7.1 \%$ in the back section. Chi square tests showed no significant difference. But when pro-war moral frames are compared with anti-war alternative frames in terms of prominence there is a significant difference between the two frames, with $55.6 \%$ of stories with 3 or more moral frames appearing on the front page and only $11.1 \%$ of stories with 3 or more alternative frames appearing on the front page. This suggests that stories with moral frames were more likely to be placed on the front page than stories with alternative frames. And with the dominance and strategic placement of pro-war moral frames in the stories of the New York Times in the buildup to the 2003 Iraqi war, it could be argued that the rational for the war was morally framed. 
Table 2a. Placement of Pro-war Moral Frames

\begin{tabular}{|c|c|c|c|c|}
\hline & $\begin{array}{l}\text { No moral } \\
\text { frames }\end{array}$ & 1-2 moral & \begin{tabular}{|c|}
$\begin{array}{c}3 \text { or more } \\
\text { moral }\end{array}$ \\
\end{tabular} & Total \\
\hline $\begin{array}{l}\text { Front page } \\
\text { Count } \\
\text { \% within placement of story }\end{array}$ & $\begin{array}{c}8 \\
17.8 \%\end{array}$ & $\begin{array}{c}12 \\
26.7 \%\end{array}$ & $\begin{array}{c}25 \\
55.6 \%\end{array}$ & $\begin{array}{c}45 \\
100 \%\end{array}$ \\
\hline $\begin{array}{l}\text { Front section } \\
\text { Count } \\
\text { \% within placement of story }\end{array}$ & $\begin{array}{c}46 \\
36.8 \%\end{array}$ & $\begin{array}{c}48 \\
38.4 \%\end{array}$ & $\begin{array}{c}31 \\
24.8 \%\end{array}$ & $\begin{array}{c}125 \\
100 \%\end{array}$ \\
\hline $\begin{array}{l}\text { Back section } \\
\text { Count } \\
\text { \% within placement of story }\end{array}$ & $\begin{array}{c}18 \\
64.3 \%\end{array}$ & $\begin{array}{c}5 \\
17.9 \%\end{array}$ & $\begin{array}{c}5 \\
17.9 \%\end{array}$ & $\begin{array}{c}28 \\
100 \%\end{array}$ \\
\hline $\begin{array}{l}\text { Count } \\
\% \text { within placement of story }\end{array}$ & $\begin{array}{c}72 \\
36.4 \%\end{array}$ & $\begin{array}{c}65 \\
32.8 \%\end{array}$ & $\begin{array}{c}61 \\
30.8 \%\end{array}$ & $\begin{array}{c}198 \\
100 \%\end{array}$ \\
\hline
\end{tabular}

Note: $X^{2}(4, \mathrm{~N}=198)=25.83, \mathrm{p}<0.001$

Source: Author's estimations.

Table 2b. Placement of Anti-war Alternative Frames

\begin{tabular}{|c|c|c|c|c|}
\hline & $\begin{array}{c}\text { No alternative } \\
\text { frames }\end{array}$ & $\begin{array}{c}1-2 \\
\text { alternative }\end{array}$ & $\begin{array}{l}3 \text { or more } \\
\text { alternative }\end{array}$ & Total \\
\hline $\begin{array}{l}\text { Front page } \\
\text { Count } \\
\text { \% within placement of story }\end{array}$ & $\begin{array}{c}30 \\
66.7 \%\end{array}$ & $\begin{array}{c}10 \\
22.2 \%\end{array}$ & $\begin{array}{c}5 \\
11.1 \%\end{array}$ & $\begin{array}{c}45 \\
100 \%\end{array}$ \\
\hline $\begin{array}{l}\text { Front section } \\
\text { Count } \\
\text { \% within placement of story }\end{array}$ & $\begin{array}{c}71 \\
56.8 \%\end{array}$ & $\begin{array}{c}33 \\
26.4 \%\end{array}$ & $\begin{array}{c}21 \\
16.8 \%\end{array}$ & $\begin{array}{c}125 \\
100 \%\end{array}$ \\
\hline $\begin{array}{l}\text { Back section } \\
\text { Count } \\
\text { \% within placement of story }\end{array}$ & $\begin{array}{c}19 \\
67.9 \%\end{array}$ & $\begin{array}{c}7 \\
25 \%\end{array}$ & $\begin{array}{c}2 \\
7.1 \%\end{array}$ & $\begin{array}{c}28 \\
100 \%\end{array}$ \\
\hline $\begin{array}{l}\text { Count } \\
\% \text { within placement of story }\end{array}$ & $\begin{array}{l}120 \\
60.6 \%\end{array}$ & $\begin{array}{c}50 \\
25.3 \%\end{array}$ & $\begin{array}{c}28 \\
14.1 \%\end{array}$ & $\begin{array}{c}198 \\
100 \%\end{array}$ \\
\hline
\end{tabular}

Source: Author's estimations.

The second research question as to how New York Times used sources to reinforce or challenge the US government official moral rhetoric for the war was answered in two parts. The first part involved determining the extent to which US official sources were used as compared to Iraqi or other sources. This involved an analysis of the sources using descriptive statistical methods. The result as shown in Table 3 indicates that in terms of dominance US official sources were used in 145 stories within a range of 1-18 times per story with a sum total of 914 times. Overall, $72.5 \%(\mathrm{~N}=145)$ of all the stories contained at least one US official source. Iraqi sources on the other hand were used in 38 stories within a range of 1-12 times per story with a sum total of 161 . Overall, $19 \%(\mathrm{~N}=38)$ of all the stories contained at least one Iraqi source. The disparity between use of official US sources, Iraqi sources and other sources clearly indicates that the New York Times heavily relied on US official sources in framing the stories of the conflict. 
Table 3. Use of Sources

\begin{tabular}{|l|c|c|c|}
\hline Source & N of stories & Range within stories & Sum \\
\hline Official US sources & 145 & $1-18$ & 914 \\
\hline US non-government sources & 62 & $1-11$ & 204 \\
\hline France, Russia, Germany, China & 55 & $1-13$ & 247 \\
\hline All other sources & 53 & $1-9$ & 132 \\
\hline UN sources & 42 & $1-8$ & 124 \\
\hline Iraqi sources & 38 & $1-12$ & 161 \\
\hline Sources from other Arab countries & 22 & $1-11$ & 115 \\
\hline Antiwar groups & 6 & $1-9$ & 30 \\
\hline International bodies & 6 & $1-6$ & 13 \\
\hline
\end{tabular}

Source: Author's estimations.

In terms of prominent positioning of sources Table 4 shows that of all the stories containing US official sources, those on the front page contained significantly more US sources $(M=10.43)$ than those in the front section $(M=4.82)$ or those in a back section $(M=2.73), F(2,142)=37.20, p<0.001$. And when compared with Iraqi sources there is a significant difference as the distribution of the use of Iraqi sources in Table 4 shows: front page $(\mathrm{M}=2.33)$, front section $(M=5.20)$, and back section $(M=3.0)$. This means that stories with official US sources were more likely to appear on the front page than in the front or back sections. And stories with Iraqi sources were less likely to appear on the front page.

Table 4. Summary of US and Iraqi Sources

\begin{tabular}{|c|c|c|c|c|}
\hline & N of stories & Mean & Std. Deviation & Std. Error \\
\hline US official sources & & & & \\
Front page & 44 & 10.43 & 4.52 & 0.682 \\
Front section & 84 & 4.82 & 3.75 & 0.410 \\
Back section & 15 & 2.73 & 2.15 & 0.556 \\
Total & 143 & 6.33 & 4.77 & 0.400 \\
\hline Iraqi sources & & & & \\
Front page & 12 & 2.33 & 1.37 & 0.396 \\
Front section & 25 & 5.20 & 3.54 & 0.709 \\
Back section & 1 & 3.00 & & \\
Total & 38 & 4.24 & 3.25 & 0.527 \\
\hline
\end{tabular}

Source: Author's estimations.

A correlation of sources and frames in Table 5 answers the second part of research question two as to how New York Times used sources to reinforced or challenge the US government official moral rhetoric for the 2003 Iraqi war. A breakdown of Table 5 shows that there is a significant correlation between US official sources and moral frames $(\mathrm{r}=0.38)$, and there is a significant correlation between other sources and alternative or pro-diplomatic frames $(\mathrm{r}=0.35)$. And since the US official sources were prominent and dominant in the stories, it means that the New York Times reinforced the moral rhetoric for the 2003 Iraqi war, which is associated with official US sources in the findings. This means that since there is a strong correlation between US official sources and moral 
frames, giving prominence and dominance to these official sources was indirectly reinforcing their moral frames. There is also a significant correlation between alternative frames and other sources, and it means that if other sources dominated the stories, pro-diplomatic frames would most likely have been reinforced.

The findings of the second research question are consistent with the theoretical position that the media favor governmental and institutional sources more than other news sources (Ericsson, Baranek, \& Chan, 1991). The findings also affirm the theoretical position that in political conflicts, it is the frame of the dominant power in the conflict that gets represented (Gitlin, 1980; Wolfsfeld, 1997).

Table 5. Correlations of Sources and Frames

\begin{tabular}{|l|c|c|c|}
\hline Sources & $\boldsymbol{N}$ & Moral frames & Alternative frames \\
\hline US official sources & 145 & $0.38^{*}$ & 0.10 \\
\hline US non-government sources & 62 & 0.02 & 0.19 \\
\hline Iraqi sources & 38 & -0.30 & -0.02 \\
\hline Arab sources & 22 & -0.33 & -0.05 \\
\hline France, Germany, Russia, China & 55 & 0.08 & $0.35^{*}$ \\
\hline UN sources & 42 & -0.09 & 0.16 \\
\hline Sources not included above & 53 & -0.23 & -0.22 \\
\hline
\end{tabular}

Note: *Correlation is significant, $\mathrm{p}<0.01$.

Source: Author's estimations.

\section{Discussion and Conclusions}

This study examined New York Times' coverage of the US - Iraqi conflict in the build up to the 2003 Iraqi war to assess the role of the news media in public opinion formation and framing of support for or against the war. The study found that pro-war moral frames dominated and defined the stories of the New York Times in the buildup to the war. Anti-war alternative frames were given limited space, and the news stories gave prominence to US official sources and their interpretation of the conflict. And in conflict situations, where competing actors advance moral frames to justify their positions and win public support (Miller \& Riechert, 2001), when the frames of one party in a conflict are given prominence and dominance in news coverage, those frames define the situation, silencing alternative frames and legitimizing the dominant frames in the public view. The choice of sources in stories of conflict shapes the discussion and understanding of the conflict. And so by giving prominence and predominance to the official US sources, the New York Times justified and legitimized the official position through their stories. And in this way it can be argued that the New York Times contributed to making a case for and providing a moral justification for the 2003 Iraqi war.

One implication of these findings is that since moral frames exert a "strong emotive appeal" (Andsager, 2000), when reinforced in the media in a prewar period they serve as a moral justification for war, which can sway public 
opinion for war. For the reinforcement of frames in the media, when coupled with the exclusion of alternative frames, serves to legitimize the projected frames and indirectly delegitimize any position contrary to the dominant frame.

Findings of this study are consistent with previous studies of coverage of international conflicts involving the US. A study of US press coverage of the 1986 US-Libya conflict found that US official sources dominated and defined the news stories of the conflict (Hertog, 2000). Hertog (2000) found "public patriotism" a major source of influence on the lopsided coverage of US - Libya conflict. An earlier study found that when a conflict involves the US, US news media "abandon their adversary role and become teammates of officialdom" (Graber, 1980, as cited in Hertog, 2000). But if in conflict situations, "journalists' feelings of patriotism may lead to supportive coverage" (Hertog, 2000 , p. 614) instead of balanced reporting, it is crucial that journalism's role in international conflicts be reevaluated and redefined by scholars and practitioners since objective and balanced reporting of conflicts is key to society's understanding conflicts and finding ways conflicts can be transformed. News coverage of pre-war period, which this study focused on, is a critical period of public opinion formation for or against war. Machiavelli (1521) in The Art of War describes this period as the period when people are "animated for war" (as cited in Smith, 2002, p. 2). But the pre-war period is also a time when moral justification against war can be mobilized, with the news media playing a key role in this process. 


\section{Negative moral frames}

\section{Appendix I: Frames for the study}

- Saddam evil - reference to his brutality or his regime as a dictatorship

- Iraq theatre of WMD - reference to WMD, unconventional weapons, chemical, nuclear or biological weapons

- $\quad$ Links with September 11 attacks on the US

- Threat to US - Iraq as posing a military or terrorist threat to the US

- Threat to the Middle East - Iraq posing a military threat to the region

- Threat to the Iraqis - reference to Iraqi regime's use of chemical weapons against the Kurds or other Iraqis

- $\quad$ Threat to the world - Iraq posing a military threat to the world

- $\quad$ Links with al Qaeda terrorist network

- Iraq is in violation of UN resolutions

\section{Positive moral frames}

- To promote or ensure peace in the Middle East region - explicit statements

- To protect the freedom of the Iraqis - explicit statements

- To promote democracy - explicit statements

\section{Alternative moral frames}

- War or pre-emptive military action dangerous

- Military action should be last resort

- War will cause suffering

- War will cause more problems

- More time to UN weapons inspectors

- $\quad$ Iraq complying with UN weapons inspectors

- No war/war is not the answer

\section{Appendix II: Sources for the study}

- $\quad$ George W. Bush - the president of the US

- $\quad$ Ari Fleischer (White House Press Secretary)

- Other White House Sources - includes all other sources from the White House other than the president and the press secretary

- $\quad$ US Congress - attribution to the either US Senate or House

- US Congressional leaders or aides - either Senate or House Leaders or their aides

- $\quad$ Donald Rumsfeld (Defense Secretary)

- Colin Powell (Secretary of State)

- $\quad$ Condoleezza Rice (National Security Adviser)

- Central Intelligence Agency (CIA) - all sources from CIA

- US Republican Congress member

- US Democrat Congress member

- US Non-government sources - these are all other US sources that are non-governmental (individuals and bodies), such as Carnegie Foundation,etc.

- British sources - includes both government, non-governmental and individual sources

- $\quad$ Saddam Hussein - Iraqi president

- Iraqi official sources - all other Iraqi official sources apart from Saddam Hussein

- Iraqi Non-government sources

- French sources - government, non-governmental and individual sources

- German sources - government, non-governmental and individual sources

- Russian sources - government, non-governmental and individual sources

- Chinese sources - government, non-governmental and individual sources

- $\quad$ Kofi Anan (UN Secretary General)

- Hans Blix and other UN weapons inspector

- $\quad$ All other UN sources not listed above

- Antiwar groups

- International non-governmental bodies

- All other sources countries and groups not listed above 


\section{References}

Andsager, J. (2000). How interest groups attempt to shape public opinion with competing news frames. Journalism and Mass Communication Quarterly, 77(3), 577-592.

Atkinson, P. (1999). Deconstructing media mythologies of ethnic war in Liberia. In T. Allen \& J. Seaton (eds.), The Media of Conflict (pp. 192-218). London: Zed Books.

Berelson, B. (1952). Content Analysis in Communication Research. Illinois: The Free Press.

Bowie, J. (1999). Out of their Hands: Framing and its impact on New York Times and Television coverage of Indians and Indian Activism, 1968-79. AEJMC Conference Paper, October 2, 1999. Retrieved from http://list.msu.edu/cgi-bin/ wa?S1=aejmc.

Detenber, B., McLeod, D., \& Malinkina, O. (1999). Framing Effects of Television News Stories about a High Visibility Protest Issue. ICA Conference Paper. San Francisco, May 1999.

Dickerson, D. L. (2001). "Framing Political Correctness": The New York Times' tale of two professors. In S. D. Reese, O. Gandy, Jr., \& A. Grant (eds.), Framing Public Life: Perspectives on Media and Our Understanding of the Social World (pp. 163-174). Mahwah, NJ: Lawrence Erlbaum Associates, Publishers.

Domke, D., Shah, D., \& Wackman, D. (2000). Rights and morals, issues, and candidate integrity: insights into role of the news media. Political Psychology, 21(4), 641-663.

Domke, D., Shah, D., \& Wackman, D. (1998). "Moral Referendums": Values, news media, and the process of candidate choice. Political Communication, 15, 301321.

Downs, D. (2002). Representing gun owners: Frame identification as social responsibility in news media discourse. Written Communication, 19(1), 44-75.

Durham, F. (2001). Breaching powerful boundaries: A postmodern critique of framing. In S. D. Reese, O. Gandy, Jr., \& A. Grant (eds.), Framing Public Life: Perspectives on Media and Our Understanding of the Social World (pp. 123136). Mahwah, NJ: Lawrence Erlbaum Associates, Publishers.

Entman, R. (1993). Framing toward clarification of a fractured paradigm. Journal of Communication, 43(4), 51-58.

Ericsson, R., Baranek, P., \& Chan, J. (1991). Representing Order: Crime, Law, and Justice in the News Media. Toronto: University of Toronto Press.

Fulglsang, R. (2001). Framing the motorcycle outlaw. In S. Reese, O. Gandy, Jr., \& A. Grant (eds.), Framing Public Life (pp. 185-194). Mahwah, NJ: Lawrence Erlbaum Associates, Publishers.

Ghanem, S. (1997). Filling in the tapestry: The second level of agenda setting. In D. McCombs (eds.), Communication and Democracy: Exploring the Intellectual Frontiers in Agenda-setting Theory. Mahwah, NJ: Lawrence Erlbaum Associates.

Gitlin, T. (1980). The Whole World is Watching. Berkeley: University of California Press.

Halliday, F. (1999). Manipulation and limits: Media coverage of Gulf war, 1990-91. In T. Allen \& J. Seaton (eds.), The Media of Conflict (pp. 127-146). London: Zed Books.

Hansen, A., Cottle, S., Negrine, R., \& Newbold, C. (1998). Mass Communication Research Methods. New York: New York University Press. 
Hawk, G. (ed.). (1992). Africa's Media Image. New York: Praeger.

Hertog, J. (2000). Elite press coverage of the 1986 US-Libya conflict: A case study of tactical and strategic critique. Journalism and Mass Communication Quarterly, 77(3), 612-627.

Iyengar, S. (1991). Is Anyone Responsible? How Television Frames Political Issues. Chicago: University of Chicago Press.

Leopold, M. (1999). "The war in the North": Ethnicity in Ugandan press explanations of conflict, 1996-97. In T. Allen \& J. Seaton (eds.), The Media of Conflict (pp. 219-243). London: Zed Books.

Lichtenberg, J. (2001). The Ethics of retaliation. Philosophy and Public Policy Quarterly, 21(4), 4-8.

Maher, M. (2001). Framing: An emerging paradigm or a phase of agenda setting? In S. D. Reese, O. Gandy, Jr., \& A. Grant (eds.), Framing Public Life: Perspectives on Media and Our Understanding of the Social World (pp. 83-94). Mahwah, NJ: Lawrence Erlbaum Associates, Publishers.

McNulty, M. (1999). Media ethnicization and the international response to war and genocide in Rwanda. In T. Allen \& J. Seaton (eds.), The Media of Conflict (pp. 268-286). London: Zed Books.

Miller, M. \& Riechert, B. (2001). The Spiral of opportunityand frame resonance: Mapping the issue cycle in news and public discourse. In S. Reese, O. Gandy, Jr., \& A. Grant (eds.), Framing Public Life (pp. 107-121). Mahwah, NJ: Lawrence Erlbaum Associates Publishers.

Norris, P., Kern, M., \& Just, M. (2003). Framing terrorism. In P. Norris, M. Kern, \& M. Just (eds.), Framing Terrorism: The News Media, the Government and the Public. New York: Routledge.

Pan, Z., \& Kosicki, G. (2001). Framing as a strategic action in public deliberation. In S. Reese, O. Gandy, Jr. \& A. Grant (eds.), Framing Public Life (pp. 35-65). Mahwah, NJ: Lawrence Erlbaum Associates Publishers.

Paterson, C. (2001). The transference of frames in global television. In S. Reese, O. Gandy, Jr., \& A. Grant (eds.), Framing Public Life (pp. 337-353). Mahwah, NJ: Lawrence Erlbaum Associates Publishers.

Peters, J. (2003). Rhetoric of Righteous Victimage. A paper presented at University of Iowa Communication Studies Conference, 17 October 2003.

Rendall, S. \& Broughel, T. (2003). Amplifying officials, squelching dissent: Fairstudy finds democracy poorly served by war coverage. Fair Extra, May/June (2003). Retrieved from www.fair.org/extra/0305/warstudy.html.

Rhee, J. W. (1997). Strategy and issue frames in election campaign coverage: A social cognitive account of framing effects. Journal of Communication, 47, 26-48.

Seaton, J. (1999). The New 'Ethnic' Wars and the Media. In T. Allen, \& J. Seaton (eds.), The Media of Conflict. London: Zed Books.

Semetko, H. \& Valkenburg, P. (2000). Framing European politics: A Content analysis of the press and television news. Journal of Communication, Spring 2000, 93 109.

Shah, D., Domke, D., \& Wackman, D. (2001). The effects of value-framing on political judgment and reasoning. In S. Reese, O. Gandy, Jr., \& A. Grant (eds.), Framing Public Life (pp. 227-243). Mahwah, NJ: Lawrence Erlbaum Associates, Publishers.

Shoemaker, P. \& Reese, S. (1996). Mediating the Message: Theories of Influence on Mass Media Content. White Plaines, NY: Longman Publishers USA.

Smith, J. (2002). The Media and Moral Force, Keynote address at Media, War, and Terrorism symposium, Hebrew University, Jerusalem, Israel (May 20, 2002). 
Sofos, S. (1999). Culture, media and politics of disintegration and ethnic division in former Yugoslavia. In T. Allen \& J. Seaton (eds.), The Media of Conflict (pp. 162-174). London: Zed Books.

Wakiaga, E. (1998). Stereotyping and the Work of Foreign Correspondents. University of Iowa: Unpublished Master's Thesis.

Wolfsfeld, G. (1997). Media and political conflict. Cambridge: University Press.

Zoch, L. (2001). What's really important here?: Media self-coverage in the Susan Smith trial. In S. Reese, O. Gandy, Jr., \& A. Grant (eds.), Framing Public Life (pp. 195-205). Mahwah, NJ: Lawrence Erlbaum Associates, Publishers. 
